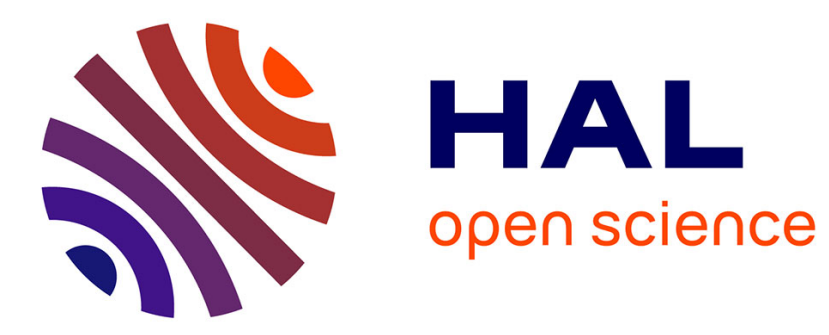

\title{
Evidence for marine production of isoprene
}

Bernard Bonsang, Claude Polle, Gérard Lambert

\section{To cite this version:}

Bernard Bonsang, Claude Polle, Gérard Lambert. Evidence for marine production of isoprene. Geophysical Research Letters, 1992, 19 (11), pp.1129-1132. 10.1029/92GL00083 . hal-03583675

\section{HAL Id: hal-03583675 \\ https://hal.science/hal-03583675}

Submitted on 22 Feb 2022

HAL is a multi-disciplinary open access archive for the deposit and dissemination of scientific research documents, whether they are published or not. The documents may come from teaching and research institutions in France or abroad, or from public or private research centers.
L'archive ouverte pluridisciplinaire HAL, est destinée au dépôt et à la diffusion de documents scientifiques de niveau recherche, publiés ou non, émanant des établissements d'enseignement et de recherche français ou étrangers, des laboratoires publics ou privés. 


\title{
EVIDENCE FOR MARINE PRODUCTION OF ISOPRENE
}

\author{
Bernard Bonsang, Claude Polle, and Gérard Lambert \\ Centre des Faibles Radioactivités, Laboratoire mixte CNRS/CEA, Gif-sur-Yvette, France.
}

Abstract. New data obtained in the Mediterranean Sea and Pacific Ocean show that isoprene could be produced in sea water by biological processes, leading to concentrations in the ppb range $\left(10^{-9}\right.$ liter of gas per liter of water).

Taking into account Henry's constant for isoprene in water and the very low concentrations measured in the marine atmosphere, the superficial sea water is supersaturated in isoprene by one or two orders of magnitude. From these observations, an oceanic flux of the order of $1.2 \mathrm{Mt}$ per year of isoprene can be estimated.

This is a small value, as compared with the marine fluxes of the other NMHC; it is also practically negligible in the global burden of isoprene. However, because of its short lifetime in air, isoprene in remote marine atmosphere, entirely originates from superficial seawater, it could be therefore an useful tracer of marine emissions of gaseous compounds.

\section{Introduction}

For most of the natural non-methane hydrocarbons (NMHC), in addition to a continental source related to vegetation and biological processes within the soil, a significant marine source has been recognized and roughly evaluated [Lamontagne et al., 1973; Bonsang et al., 1988a; Kanakidou et al., 1988; Plass et al., 1991]. Isoprene (2methyl-1,3-butadiene) has been identified as the most important $\mathrm{NMHC}$, and its production from vegetation could be of the order of $400 \mathrm{Mt}$ per year [Zimmerman, 1979; Lamb et al., 1987; Rasmussen and Khalil, 1988], i.e. almost as much as total methane emission. Most NMHC's have natural biogenic sources in both continental and marine regions, however, to our knowledge, no marine source of isoprene has been previously identified. Here we present new data obtained in the Mediterranean Sea and Pacific Ocean, showing that this gas is probably produced in sea water by biological processes, and supersaturated in superficial sea water with respect to the atmosphere.

\section{Sea water measurements}

Sea water samples were collected during five oceanographic campaigns. Surface sea waters were sampled in May 1987 in the North Pacific near Hawaii during the cruise RE 8703 (Radiatively Important trace Species campaign organized by NOAA, Miami), and in June 1987 in the South Pacific 5 miles N E of Hao atoll (Tuamotus) and in April 1990 near several other atolls in that region. In October 1989 and May 1990 in the Mediterranean, half way between Nice and Corsica (43⒊ $\mathrm{N}$; 0729' E) surface and deep waters were collected down to $1500 \mathrm{~m}$ depth during the DYFAMED experiment (Dynamique des Flux en Mediterranée Occidentale, France JGOFS program). One additional 1000 meter profile was obtained in April 1990 in the South Pacific near Tikehau atoll (Tuamotus). Sea water samples were collected at depth with $10 \mathrm{~L}$ "Go Flo" oceanographic bottles.

Immediately after the sample collection, 6 liters of seawater were transferred into a stainless steel canister fitted with two metal bellow valves. As soon as this procedure was completed, no gas exchange was possible between the trapped seawater and ambient air. The samples were

Copyright 1992 by the American Geophysical Union.

Paper number 92GL00083

0094-8534/92/92GL-00083\$03.00 immediately treated on board using a "head space"equilibration technique [Bonsang et al., 1988]. For this purpose, a 2-liter stripping chamber was first evacuated and rinsed with ultra pure helium 1 . This procedure was repeated three times and then the chamber was filled with 1.5 liter of sea water. Ultrapure helium was then bubbled into the chamber at a flow rate of $100 \mathrm{ml} / \mathrm{min}$ for 1 hour. Stripped gases were collected in a 6-liter cylinder until a slight overpressure was obtained $(1.2 \mathrm{~atm})$. These canisters were identical to those used for atmospheric samples [Bonsang et al., 1988a].These samples were stored on board at room temperature and subsequently analysed in the laboratory.

A theoritical extraction efficiency of $93 \%$ for isoprene and comprised between 97 and $99 \%$ for most of the other hydrocarbons for this whole procedure can be calculated from the NMHC's Henry's constant and the ratio of the volumes of helium and seawater equilibrated. It was compared to the measured efficiency determined from successive extractions from a given seawater sample. This experimental efficiency was found to be better than $95 \%$ for the $\mathrm{C}_{2}-\mathrm{C}_{6} \mathrm{NMHC}$ and $90 \%$ for isoprene. Taking into account this efficiency, and the minimum detectable limit for isoprene by our chromatographic procedure, the detection limit of isoprene in the seawater samples was estimated at $20 \times 10^{-12}$ liter/liter (20 pptv).

Laboratory tests were made in order to check the storage efficiency of the NMHC in the canisters. Analyses were performed on air samples containing $0.05-0.1 \mathrm{ppbv}$ and 2 ppby of isoprene as well as other NMHC in the sub-ppb levels. The storage efficiency of isoprene increases with its concentration and decreases with the storage duration. For a 2-ppb level of isoprene, no significant losses (within the accuracy of the measurements) were found over a six-month period. On the opposite, detectable losses of isoprene (and hexene) were found for sub-ppb levels. For a typical concentration of $0.08 \mathrm{ppbv}$ of isoprene, corresponding to a seawater sample content of $0.3 \mathrm{ppbv}$, significant losses reached about $14 \%$ over a 4-week period and $50-70 \%$ over a 6-month period [Kanakidou, 1988 ]. For this reason the samples were analysed in the laboratory within one month after their collection.

NMHC were analyzed using a technique previously described [Bonsang et al., 1988; Kanakidou, 1988] and based on capillary gas chromatography with a detection by flame ionization. A porous-layer open tubular column $\left(\mathrm{Al}_{2} \mathrm{O}_{3} / \mathrm{KCl}\right)$ was used, and the gas sample concentrated on a tenax GC trap cooled at $-120^{\circ} \mathrm{C}$; the samples were thermodesorbed from the trap and introduced into the column during a temperature program starting at $-80^{\circ} \mathrm{C}$. A typical chromatogram showing the presence of isoprene at a retention time of $21.75 \mathrm{~min}$, at a concentration of $0.695 \mathrm{ppbv}$ in a sea water sample, is shown in Figure 1.

In order to ascertain the presence of isoprene in our samples the following available isomers were studied: 3 methyl-1,2-butadiene, cyclopentene, cis-1,3-pentadiene, trans-1,3-pentadiene, 1,4-pentadiene, and 1-pentyne. We checked that their retention times were significantly different from that of isoprene.

Finally, isoprene was identified in several samples by Gas chromatography- mass spectrometry using a 5890 Hewlett Packard GC, coupled with a 5970 series mass selective detector.

A possible contamination by the extraction system was first checked. Ultra pure helium, previously analyzed for its hydrocarbon content, was introduced in the bubbling chamber at the flow rate and over a time period identical to those of the 


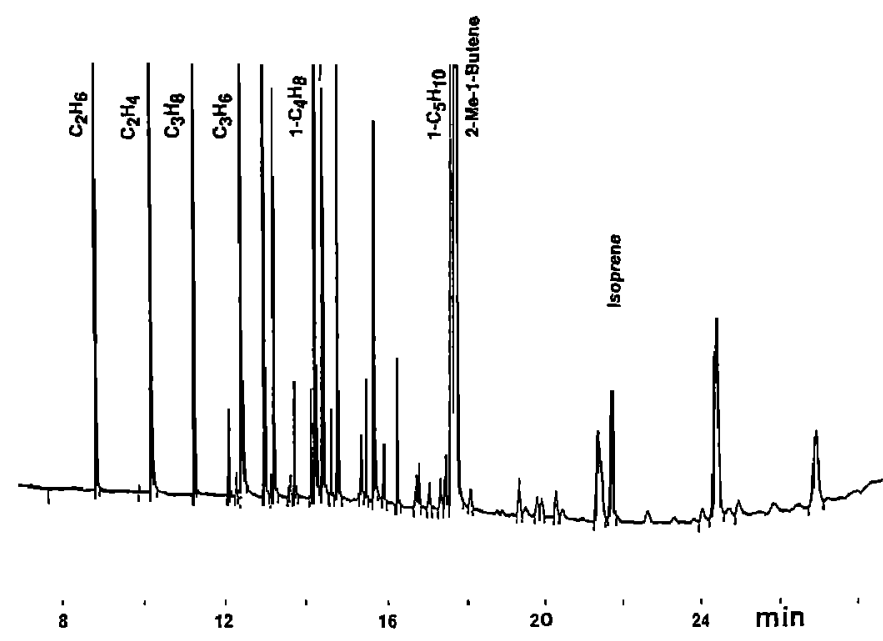

Fig 1. Chromatogram of dissolved NMHC in seawater . experimental conditions. A very slight contamination of few pptv was observed for alkanes and alkenes. No detectable contamination (i.e. below 2 pptv) was noted for isoprene. In a second step, the contamination by the "Go Flo" sampling bottles was also checked. For this purpose, through several experiments, distilled as well as sea water was introduced in the bottle and stored for two hours. The NMHC content of the stored water was analyzed and compared to the initial content of the water used. No significant difference was foundwithin the accuracy of our measurements.

Three daytime profiles and one nighttime profile are shown in Figures $2 a$ to $2 c$, together with those of ethene and propene and typical fluorescence and temperature profiles obtained in Mediterranean. A more or less sharp maximum is observed for these NMHC at $40 \mathrm{~m}$ depth in both the Mediterranean and the South Pacific, reaching up to 3 ppbv for isoprene. In the Mediterranean, the isoprene maximum appears slightly above the fluorescence peak situated at $60 \mathrm{~m}$ depth. Below $100 \mathrm{~m}$ in Mediterranean and $200 \mathrm{~m}$ in Pacific, isoprene concentrations are very low, but often measurable. The isoprene content decreases more or less rapidly from the depth of the concentration maximum to the sea surface, where its concentration is of the order of 0,15 to $0,5 \mathrm{ppby}$ in the Mediterranean and a little more in the Pacific.
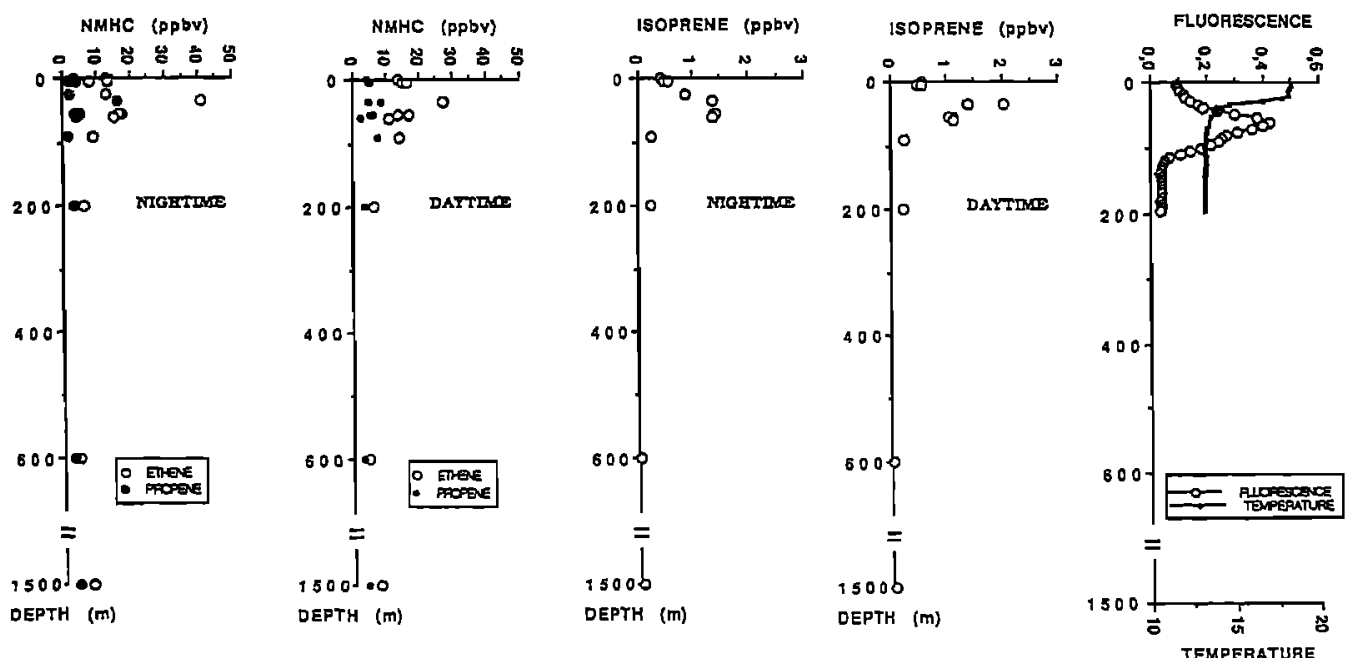

Fig. 2-a Vertical profiles in seawater of fluorescence (arbitrary units), temperature $\left({ }^{\circ} \mathrm{C}\right)$, isoprene, ethene and propene (ppbv

or $10^{-9}$ litre of gas per litre of water at $25^{\circ}$ ) during the DYFAMED campaign in October 1989.

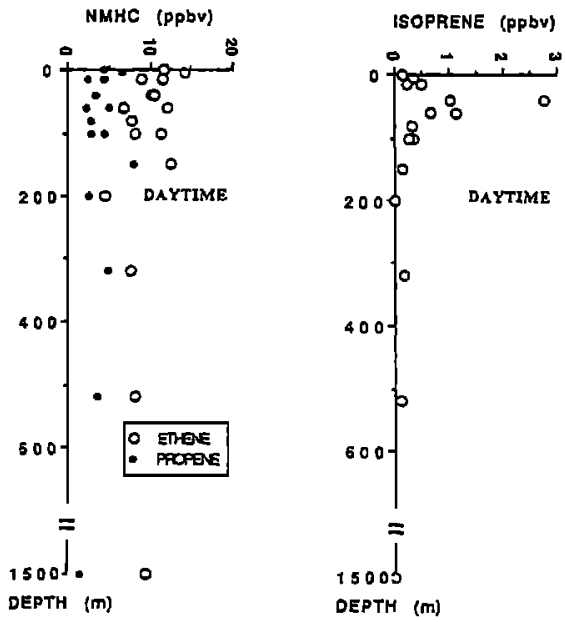

Fig. 2-b Vertical profiles in seawater of fluorescence, temperature, isoprene ethene and propene during the DYFAMED campaign in May 1990.
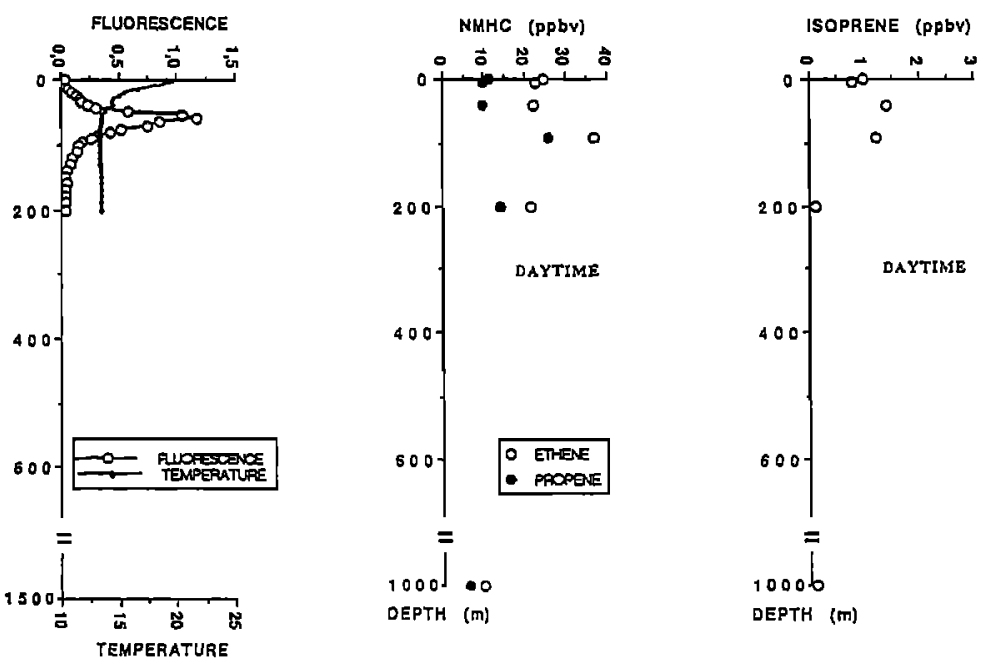

Fig. 2-c Vertical profiles in seawater of isoprene ethene and propene in South Pacific Ocean (April 1990). 
Even though the presence of isoprene in sea water is almost certainly related to biological activity, its cycle of production, transport and destruction remains to be understood. This cycle seems to be characterized by the following observations:

-the vertical profiles of isoprene in the Mediterranean are very similar in October and May, despite the differences in temperature profiles and, more particularly, the thermocline depth (Figures 2a and 2b); $A$ similarity between the distributions of isoprene and fluorescence can be noted, however, it appears that isoprene systematically peaks at shallower depth relative to fluorescence. For this reason a direct link between isoprene and chlorophyll cannot be established, but a production process by degradation of an organic precursor is highly probable.

-no significant variation was observed between day and night, as shown in Figure 2a, nor during 36 hours of monitoring the isoprene concentration at $15 \mathrm{~m}$ depth (Figure 3).Unfortunately no time series were available for samples collected at the peak maximum.

-these profiles can be very different from those obtained simultaneously for other NMHC. Particularly, ethene and propene, which are the main hydrocarbon found in seawater present in one case (Figure 2a) a maximum close to that of isoprene, but this effect is not observed in the second experiment (Figure 2b) .

These observations could be accounted for by a biochemical production of isoprene in the euphotic layer followed by its photodestruction in this layer with a residence time of several days.

All these processes result in the presence of isoprene in surface sea water, at concentrations between 0.15 and 2.22 ppby, as shown in Table 1, which gathers all available data with the corresponding ethene and propene figures.

\section{Isoprene in marine atmosphere}

Isoprene is very rapidly oxided in air by $\mathrm{O}_{3}, \mathrm{OH}$ and $\mathrm{NO}_{3}$ radicals with kinetic constants of $120 \times 10^{-18}, 102 \times$ $10^{-12}$, and $320 \times 10^{-15} \mathrm{~cm}^{3}$ molecule ${ }^{-1} \mathrm{~s}^{-1}$ respectively [Atkinson et al., 1984; Atkinson, 1986; Davenport and Singh, 1987]. Consequently, its atmospheric residence time is very short, of the order of 2 hours at noon, when the $\mathrm{OH}$ concentration is close to $10^{6} \mathrm{~cm}^{-3}$, and about twice this figure by night. For this reason, its mixing ratio remains low, even near tropical forests, where it does not exceed $10 \mathrm{ppbv}$ [Rasmussen and Khalil, 1988; Zimmerman et al., 1988; Bonsang et al., 1988], and offshore this concentration rapidly drops to very small figures usually below the usual detection limits reported of 10 pptv [Greenberg and Zimmerman, 1984].

Isoprene was also measured in atmospheric samples. These samples were collected in evacuated stainless steel electropolished canisters at different marine sites either at ambient atmospheric pressure or with the help of a metal bellow compressor. These samples were analyzed for NMHC by gas chromatography using the same cryogenic enrichment procedure and the same analytical device as previously described for sea water samples.

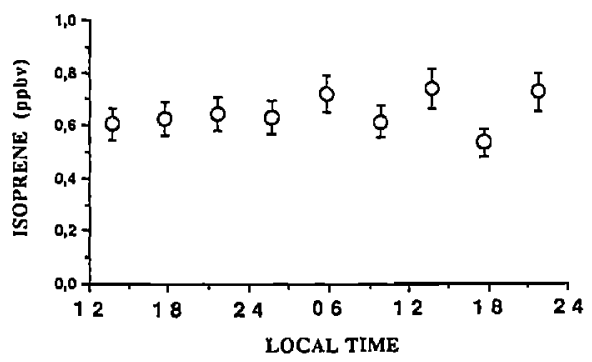

Fig. 3 Diumal variation of the isoprene concentration in seawater at $15 \mathrm{~m}$. depth (Mediterranean, May 1990).
TABLE 1. Isoprene, ethene and propene concentrations in the surface seawater

\begin{tabular}{|c|c|c|c|c|c|c|}
\hline \multirow{2}{*}{$\begin{array}{l}\text { Dare } \\
\text { May } 29 \\
1987\end{array}$} & \multirow{2}{*}{$\begin{array}{l}\begin{array}{l}\text { Local } \\
\text { time }\end{array} \\
1200\end{array}$} & \multicolumn{2}{|c|}{ Position } & \multicolumn{3}{|c|}{$\begin{array}{l}\text { Isoprene Ethene Propen } \\
\left(10^{-9} 1 \text {. of gas } / 1 \text {. of water }\right.\end{array}$} \\
\hline & & $\begin{aligned} 2395 \\
154 \%\end{aligned}$ & ( & 178 & 14 & .4 \\
\hline & 430 & $\begin{array}{r}18^{\circ} \\
140^{\circ}\end{array}$ & & 6 & 2.73 & 5.8 \\
\hline & $\begin{array}{l}0700 \\
1100 \\
1100\end{array}$ & “ & $\begin{array}{l}(2,2) \\
(2, c) \\
(2, b)\end{array}$ & & $\begin{array}{l}22 \\
21 \\
23\end{array}$ & $\begin{array}{r}12.80 \\
8.35 \\
8.51\end{array}$ \\
\hline 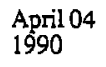 & 1400 & $\begin{array}{r}150 \\
148 \%\end{array}$ & & 0.5 & 24 & \\
\hline & $\begin{array}{l}700 \\
100\end{array}$ & $\begin{array}{r}16^{\circ} \\
145^{\circ} 3\end{array}$ & & & & \\
\hline & 400 & $\begin{array}{r}16^{\circ} \\
1442\end{array}$ & $\begin{array}{l}(5, a) \\
(5, c) \\
(5, b)\end{array}$ & & $\begin{array}{l}18 \\
32\end{array}$ & 15 \\
\hline oril & $\begin{array}{l}0600 \\
0730 \\
0730\end{array}$ & $\begin{array}{r}16^{\circ} 4 \\
143 \% 7\end{array}$ & $\begin{array}{l}(6, a) \\
(6, c) \\
(6, b)\end{array}$ & 1 & $\begin{array}{l}2 \\
2 \\
2\end{array}$ & \\
\hline 90 & $\begin{array}{l}1400 \\
1400 \\
1400\end{array}$ & $\begin{array}{r}16^{\circ 9} \\
143^{9}\end{array}$ & $\begin{array}{l}(7, a) \\
(7, c) \\
(7, b)\end{array}$ & $\begin{array}{l}2 \\
1\end{array}$ & $\begin{array}{l}18 \\
55 \\
47\end{array}$ & \\
\hline 89 & $\begin{array}{l}00 \\
05\end{array}$ & $\begin{array}{l}43^{\circ} 36^{\prime} \mathrm{N} \\
07^{\circ} 29^{\prime} \mathrm{E}\end{array}$ & & & 120 & 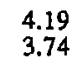 \\
\hline \multirow{3}{*}{$\begin{array}{l}\text { May } 16 \\
1990 \\
\text { May } 17 \\
1990\end{array}$} & 400 & & ) & 0.246 & & \\
\hline & 0545 & 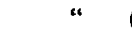 & $(8, a)$ & 0.290 & 14. & .64 \\
\hline & 2145 & 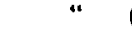 & $(8, a)$ & 0.220 & 11. & $11.1 \mathrm{~J}$ \\
\hline & 17 & “ & $(8, a)$ & 0.147 & 11.67 & 4.4 \\
\hline
\end{tabular}

(1) North Pacific; (2 to 7) South Pacific; (2) Hao atoll; (3) Tikeau atoll; (4) Fakarava atoll; (5) Kauehi atoll; (6) Makemo atoll; (7) Marutea atoll; (8) Mediterranean.

(a) Open Ocean; (b) Lagoon, (c) Pass.

Air samples were collected monthly from March 1986 to May 1987 at Amsterdam island (Terres Australes et Antarctiques Françaises), in the midle of southern Indian Ocean and analyzed after a time lag of about six months. The isoprene mixing ratio was always less than our detection limit of 2 pptv; however, as previously pointed out, very significant losses in the canisters for these very low concentration prevent to conclude wether initial concentrations were higher. If so, they probably did not exceed 10 to 20 pptv.

Over the Hao atoll (Tuamotu archipelago) we have measured in air masses blowing directly from the ocean detectable levels which, however, did not exceed 36 pptv (Table 2).

Taking into account Henry's constant for isoprene in water (3.1 $\mathrm{mol} / \mathrm{mol}$ ) [Mc Kay and Shiu, 1981], the equilibrium concentration in the atmosphere should be of the order of $10^{2}$ to $10^{3}$ ppty. The superficial sea water is therefore supersaturated in isoprene by one or two orders of magnitude.

We can infer from these observations that there exists a small flux of isoprene from the sea surface toward the lower marine atmosphere. Considering the marine flux of ethene (15 Mt per year) [Bonsang et al.,1988], and taking into account respective concentrations of ethene and isoprene in surface sea water ( 15 and $0.5 \mathrm{ppbv}$ ) and a molar ratio 2.5 , its oceanic source is estimated to be of the order of $1.2 \mathrm{Mt}$ per year. This is a small value, as compared with the marine fluxes of the other NMHC; it is also practically negligible in the global burden of isoprene.

The importance of the marine source of isoprene could rather result from its short atmospheric lifetime, which 
enables ruling out any long range transport of this gas from remote continents. Moreover, it can be ascertained that, when detected in open ocean, atmospheric isoprene was outgassed from the sea surface within the last two or three hours.

A good exemple of this is given by the rapid and strong variations observed over the Hao atoll for the isoprene mixing ratios, relative to those of ethene and propene (Table 2 ). In effect, the ratio ethene/isoprene in the water of the South Pacific is between 19 and 79 , with an average of 37 . By contrast, we can see in Table 2 that in air this ratio varies between 39 and values as high as 1197 . Similar observations can be done for propene. This could be accounted for by the existence of discontinuous emissions of NMHC followed by a rapid decay of isoprene relative to ethene and propene during time spans of a few hours.

TABLE 2. Isoprene, ethene and propene concentrations in the marine atmosphere over the Hao atoll

\begin{tabular}{|c|c|c|c|c|c|}
\hline Date & $\begin{array}{l}\text { Local } \\
\text { time }\end{array}$ & $\begin{array}{c}\text { Altitude } \\
\mathrm{m} .\end{array}$ & $\begin{array}{l}\text { Isoprene } \\
\text { (pptv) }\end{array}$ & $\begin{array}{l}\text { Ethene } \\
\text { (pprv) }\end{array}$ & $\begin{array}{l}\text { Propene } \\
\text { (pprv) }\end{array}$ \\
\hline $\begin{array}{l}\text { May } 31 \\
1987\end{array}$ & $\begin{array}{l}1450 \\
1430 \\
1200 \\
1200\end{array}$ & $\begin{array}{r}0 \\
100 \\
400 \\
1000\end{array}$ & $\begin{array}{l}36 \\
<2 \\
10 \\
<2\end{array}$ & $\begin{array}{r}1225 \\
865 \\
171 \\
244\end{array}$ & $\begin{array}{r}1465 \\
732 \\
936 \\
56\end{array}$ \\
\hline $\begin{array}{l}\text { June } 10 \\
1987\end{array}$ & $\begin{array}{l}1820 \\
1744\end{array}$ & $\begin{array}{r}0 \\
500\end{array}$ & $\stackrel{2}{4}$ & $\begin{array}{l}2395 \\
3944\end{array}$ & $\begin{array}{l}1779 \\
4522\end{array}$ \\
\hline $\begin{array}{l}\text { June } 11 \\
1987\end{array}$ & $\begin{array}{l}0655 \\
1000 \\
1000\end{array}$ & $\begin{array}{r}0 \\
375 \\
1595\end{array}$ & $\begin{array}{r}<2 \\
15 \\
6\end{array}$ & $\begin{array}{l}172 \\
231 \\
534\end{array}$ & $\begin{array}{r}584 \\
582 \\
1078\end{array}$ \\
\hline
\end{tabular}

\section{Conclusion}

Considering the depth profiles of dissolved hydrocarbons in seawater, it appears that isoprene presents a vertical distribution very close to that of fluorescence which mainly represents the content of chlorophyll. Therefore, it is probably produced in the subsurface by biological processes, and has a lifetime long enough in water to reach the surface where it is still supersaturated with respect to its atmospheric concentrations. Similarly to other light non methane hydrocarbons (mainly ethene and propene), it appears therefore that the ocean is also a source of isoprene for the atmosphere. Its oceanic source is estimated to be of the order of $1 \mathrm{Mt}$ /year, i.e. about one order of magnitude lower than the oceanic source of ethene.

Isoprene is rapidly destroyed in the marine atmosphere by ozone and $\mathrm{OH}$ radicals and its amospheric concentrations rarely exceed the detection limit of our technique of 2 pptv. On the whole, isoprene is probably of minor importance in the global budget of oxydants in the remote marine boundary layer, however, due to its high reactivity in the atmosphere and simultaneously its strong correlation with biological activity, the local production of its oxygenated derivatives such as aldehydes could be enhanced in eutrophic areas [Carlier et al., 1988; Arlander et al., 1990]. Besides, providing significant improvements in the detection procedure and in the accuracy of the measurement techniques for ambient levels of the order of pptv, marine isoprene could be used as a tracer of major interest in the field of sea-air exchanges.

Acknowledgments. We thank the Direction des Centres d'Expérimentation Nucléaire and the Service Mixte de Sécurité Radiologique (Commissariat à l'Energie Atomique) and more particularly J. Rancher and E. Fontaine, as well as the team of RV Korotneff, for logistic support and sample collection. C.Hertz and R.Vulpian from Direction des Etudes et Techniques Nouvelles, Gaz de France, are greatfully acknowledged for mass spectrometry analysis. This work was funded by Centre National de la Recherche Scientifique
(PIREN), and Commissariat à l'Energie Atomique. This is a CFR contribution $n^{\circ} 1231$.

\section{References}

Arlander D.W., D.R. Cronn, J.C. Farmer, F.A. Menzia, and H.H. Westberg, Gaseous oxygenated hydrocarbons in the remote marine troposphere, J. Geophys. Res.95, $1639116403,1990$.

Atkinson, R., S.M. Aschmann, A.M. Winer, and J.N. Pitts $\mathrm{J} r$., Kinetics of the gas-phase reaction of $\mathrm{NO}_{3}$ radical with a serie of dialkenes, cycloalkenes ans monoterpenes at 295 \pm IK, Environ. Sci. Technol., 18, 370-375, 1984.

Atkinson R., Kinetics and mechanisms of the gas-phase reactions of the hydroxyl radical with organic compounds under atmospheric conditions, Chem Rev. \& 69-201, 1986.

Bonsang , B., M. Kanakidou, G. Lambert, and P. Monfray, The marine source of C2-C6 aliphatic hydrocarbons, I. Atmos. Chem.. 6, 3-20, 1988a.

Bonsang , B., M. Kanakidou, and G. Lambert, Vertical profiles and fluxes of NMHC in the equatorial forest of Congo, EOS, 69, 1066, 1988b.

Bonsang, B., and G. Lambert, Air sea exchanges of non methane hydrocarbons, Proceeding of EUROTRAC Symposium 90, 81-82, 1990.

Carlier P., P. Fresnet, V. Lescoat, S. Pashalidis and G . Mouvier, Formaldehyde background levels over the Atlantic ocean during the Polarstem crossing from Bremerhaven to Rio Grande do sul, Cost 611 WP III: CEE air Pollution research report.14, S. Beilke, J. Morelli, G. Angeletti eds., 55, 1988.

Davenport J.E., and H.B. Singh, Systematic development of reactive tracer technology to determine hydroxyl radical concentrations in the troposphere, Atmos. Eny.2 21. 1969-1981, 1987.

Greenberg J.P., and P.R. Zimmerman, Nonmethane hydrocarbons in remote tropical, continental, and marine atmospheres, J. Geophys. Res. 89, 4767-4778, 1984.

Kanakidou, M., B. Bonsang, J.C. Le Roulley, G. Lambert, D. Martin, and G. Sennequier, Marine source of atmospheric acetylene, Nature. 333, 51-52, 1988.

Kanakidou, M. , Contribution à l'étude des sources des hydrocarbures légers non méthaniques dans l'atmosphère, Thèse de Doctorat. Université de Paris VI, 193 p., 1988.

Lamb, B., A. Guenther, D. Gay and H. Westberg, A national inventory of biogenic hydrocarbon emissions, Atmos. Env. 21, 1695-1705, 1987.

Lamontagne, R.A., J.W. Swinnerton and V.J. Linnenbom, $\mathrm{C}_{1}-\mathrm{C}_{4}$ hydrocarbons in the North and South Pacific, Tellus, 26, 71-77, 1973 .

Mc Kay D., and W.Y. Shiu, Critical review of Henry's law constants for chemicals of environmental interest, $\mathrm{J}$. Phys. Chem. Ref. Data, 10, 1175-1199 (1981).

Plass, C., R. Koppmann and J. Rudolph, Light hydrocarbons in the surface water of the mid-Atlantic, $\mathrm{J}$. Atmos. Chem. (in press), 1991.

Rasmussen, R.A. and M.A.K. Khalil, Isoprene over the Amazon basin, J. Geophys. Res. 93, 1417-1421, 1988.

Zimmerman , P.R. , Testing of hydrocarbon emissions from vegetation, leaf litter and aquatic surfaces, and development of a methodology for compiling biogenic emission inventories, Rep. EPA 450/4-79-004, Environ. Prot. Agency, Washington, D.C.. 1979.

Zimmerman, P.R., J.P. Greenberg, and C.E. Westberg, Measurements of amospheric hydrocarbon and biogenic emission fluxes in the Amazon boundary layer, $\mathrm{J}$. Geophys. Res. 93, 1407-1416, 1988.

B. Bonsang, C. Polle and G. Lambert, Centre des Faibles Radioactivités, Laboratoire Mixte CNRS/CEA, Avenue de la Terrasse, 91198 Gif-sur-Yvette, France.

(Received June 13, 1991; Accepted September 28, 1991) 